\title{
TRTakademi
}

ISSN 2149-9446 | Cilt 06 | Sayı 12 | Mayıs 2021 | Dijital Hayat ve Etik

\section{Sinemada Dijital Dönüşüm}

Sinemada Dijital Dönüşüm

Rıdvan Şentürk

Pruva Yayınları, Ankara, 2020, $136 \mathrm{s.}$

ISBN: 978-625-7267-01-4

\section{Mesut BOSTAN*}

Martin Scorsese yakın bir zamanda, "Sinema ölüyor." dediğinde büyük bir tartışmaya yol açmışt. Sinemada süper kahraman filmlerinin hâkimiyetinden yakınan yönetmen, bilinen anlamıyla sinemanın yok olduğunu söylüyordu. Yönetmenin lunapark tecrübesine benzettiği süper kahraman filmleri, aslında sinemada yaşanan büyük bir dönüşümün tezahürlerinden biri. Scorsese (2021), Fellini hakkında yazdığı bir anma yazısında da artık sadece mazide kalan bir sinema anlayışının ardından ağıt yakarken dijitalleşme olgusunun sinema filmini "içerik" adında genel bir kategoriye indirgediğini söylüyor. Bir Fellini filmi artık YouTube'daki bir kedi videosuyla aynı kulvarda yarışıyor ona göre. İzlenme oranlarını dikkate aldığımızda büyük arayla da kaybediyor. Dijitalleşme, sinema alanında 1990'lardan beri peyderpey sinema süreçlerini içine alarak etkisini genişleten bir olgu. Pandemiyle birlikte geleneksel dağıtım ve gösterim imkânlarının devreden çıkması ve dijital platformların film seyir tecrübesinin ana mecrası hâline gelmesiyle sinemanın dijitalleşmesi tamama ermiş görünüyor. Buna rağmen dijitalleşmenin sinemayı komünal bir tecrübe olmaktan çıkarıp seyircileri tekil içerik tüketicilerine dönüştürmesi gibi sonuçlarına yönelik bir farkındalık henüz yok. Sinemada dijitalleşme bir yandan yapım, dağıtım, gösterim süreçlerini kolaylaştırırken bir yandan da dev dijital şirketlerinin sinema üzerindeki hâkimiyetini de güçlendiriyor. Bu da dijital tekellere mahkûm olan sinema ve dizi sektöründe yapım organizasyonunun filmin kârından aldığı payı giderek düşürürken yapımcılığın taşeronlaşmasına sebep oluyor. Sinemada diji-

\footnotetext{
*Arş. Gör. Dr., Marmara Üniversitesi Iletişim Fakültesi Radyo Televizyon ve Sinema Bölümü, ORCID ID: 0000-0002-3770-3557, mesut.bostan@marmara.edu.tr.
} 
talleşmenin bu tür ekonomik ve yapısal sonuçlarının ötesinde filmin estetik ve zihinsel alımlanmasına dair de ürettiği sonuçlar söz konusu. Ancak sinemadaki sektörel ya da kültürel dönüşümlerin yanında dijitalleşmenin yarattı̆ı zihinsel etkilerin kapsamı ve mahiyeti açık olmaktan uzak. Sinema, doğuşuyla birlikte modern zihnin oluşumunda önemli bir rol oynamışt. Bugün dijitalleşmeyle sinema değişirken günümüz insanının zihniyeti de değişiyor. Dolayısıyla dijitalleşmenin diğer sonuçlarının yanı sıra ontolojik ve epistemolojik açıdan getirdikleri başlı başına bir mesele teşkil ediyor. Bu noktada Rıdvan Şentürk'ün Sinemada Dijital Dönüşüm (2020) adlı kitabı sinemada dijitalleşmenin ortaya çıkardığı felsefi sorunları tartışıyor olması açısından önem arz ediyor.

Rıdvan Şentürk; sinema, televizyon ve kültürün farklı alanlarında felsefi arka plana sahip çalışmalar yapan bir akademisyen. Doktora tezine dayanan Postmodern Kaos ve Sinema'da (2011) adlı eserinde Şentürk, teknoloji eleştirisi ekseninde bir modernite değerlendirmesi yapıyor. Batı'da postmodernizm olarak ortaya çıkan modernite eleştirisinin modernitenin zayıf yanlarını göstermesine rağmen onun yerine bir dizge öneremediğini söylüyor. Şentürk'e göre postmodern sinema da bu kapsamda güncel felsefi sorunların iyi bir yansıması olmasına rağmen bu sorunların yarattğı kaosa katkı yapmaktan başka bir işlev göremiyor. Yazarın sinema bağlamında dijitalleşme olgusuna da bağlanabilecek teknoloji eleştirisinin kıta felsefesi geleneğine temellendiği söylenebilir. Nitekim yazarın erken çalışmalarından biri olan Heidegger'in Düşünmek Ne Demektir (2009) kitabının tercümesi aynı zamanda onun felsefi referanslarından birini de ortaya koyuyor. Yine bu bağlamda Eleştirel Teori'nin Eleştirisi (2013) adlı kitabında ortaya koyduğu Frankfurt Okulu eleştirisi de onun Alman düşüncesi içerisindeki tartışmada tuttuğu tarafi ve teknoloji eleştirisi bağlamında kültür endüstrisi yaklaşımına "çatı̧̧macı" karakterinden ötürü mesafeli yaklaşthğı düşünülebilir. Bunun ötesinde teknoloji eleştirisi Şentürk'ün medya üzerine yapmış olduğu çalışmalarda önemli bir uğrak. Sinemada Dijital Dönüşüm, bu açıdan kıta felsefesi birikimi üzerinden ifade edilen teknoloji eleştirisinin yazarın kitapları arasında başlığa çıkarak temayüz ettiği ilk kitap. Aynı zamanda yazarın teorik çalışmalarının da eleştirellikle buluşan bir örneği.

Rıdvan Şentürk, Sinemada Dijital Dönüşüm'de devrim niteliğini taşıdığını söylediği sinemadaki analog düzenden dijital düzene geçişi felsefi açıdan değerlendiriyor. Sinemada analog döneme damgasını vuranın klasik gerçekçi öykü sineması olduğunu söylüyor. Dijital dönemi ise modern düşüncenin bütün ilkelerinin ihlal edildiği bir kaos şeklinde betimliyor. Dijitalleşmeyle sinemaya dair birçok durum değişirken sinemanın teknolojiye bağımlılığı devam ediyor 
Şentürk'e göre. Teknoloji üzerinden gerçekleştirdiği modernlik eleştirisi bu açıdan sinemanın dijital dönemindeki hâline de yöneliyor. Yazarın vurguladığı noktalardan biri dijitalleşmeyle birlikte sinemada anlatının geri çekilmesidir. Öte yandan görsel açıdan filmin tamamen kurgulanabilir oluşu animasyon türünü tekrar önemli hâle getirmektedir. Şentürk, analog dönemin öykü sineması tiyatro ve roman gibi anlatı sanatlarına dayanması sebebiyle görsel tabiatından kaynaklanan sanat potansiyelini tam olarak hayata geçiremediği görüşünde. Bu yüzden dijitalleşmeyle anlatının yerine görselliğin merkezi hâle gelişini sinemanın görsel bir sanat olarak temayüz etme imkânını yeniden ele geçirmesi olarak yorumluyor. Dijitalleşme bir yandan sinemanın teknoloji bağımlılığını artırırken bir yandan da sağladığı görsel imkânlarla sanat potansiyelini ona geri kazandırıyor. Şentürk'ün dikkat çektiği durumlardan bir diğeri ise dijitalleşme ile anlat sinemasından olduğu kadar gerçekçilikten de kopuluyor olmasıdır. Sinemada gerçekçiliği modernliğin tezahürlerinden biri olarak gören Şentürk, dijitalleşme ile klasik sinemanın ürettiği modern öznenin de parçalanmaya maruz kaldığını ifade ediyor. Bu parçalanma aynı zamanda modernliğin bütün ideallerinin de boşa çıkması anlamında gelir. Modernliğin bir şekilde kavrama iddiasında olduğu hakikat, dijitalleşmeyle ortaya çıkan postmodern sinemanın tümden reddettiği bir olgudur. Bilimin yerini teknoloji almıştır. Teknoloji sinema gibi insanı da dönüştürmektedir. Fiziki gerçeklikten, hakikatten ve rasyonel akıldan tamamen kopan yeni insan için klasik gerçekçiliğe dayanan öykü sineması nostaljik bir unsur olmaktan öte gitmez Şentürk'e göre.

Sinemada Dijital Dönüşüm, Rıdvan Şentürk'ün Gülme Teorileri (2016), Eleştirel Teorinin Eleştirisi ve İletişim ve Televizyon Teorileri'nde (2017) gerçekleştirdiği teori eleştirisi ile Postmodern Kaos ve Sinema'da gerçekleştirdiği modernlik eleştirisini birleştirdiği bir kitap. Bununla beraber teori eleştirisi kitaplarındaki kadar literatür yoğun bir metin değil. Modernlik ve postmodernizm eleştirisi bağlamında ise Postmodern'den daha derli toplu. Bu kitabın bir bakıma dijitalleşme üzerinden devam ettiricisi konumunda. Sinemaya odaklanma, bunu yaparken de teknoloji eleştirisini ana eksen kılma ve nihayet postmodernizm ve dijitalleşme gibi süreçleri çözümleme maksadında olmaları açısından iki kitap birbirini tamamlıyor. Ancak iki kitap, aksayan yönleriyle de birbirine benziyor. İki kitapta da söylem düzeyinde kalan ve somut örneklerle desteklenmeyen tespitler bulunuyor. Postmodern'den daha derli toplu olmasına rağmen kitap içerisinde ifade tekrarları Sinemada Dijital Dönüşüm'de de devam ediyor. Felsefi kavramların sıralanıp kullanımları da metnin anlaşılmasını zorlaştırıyor. Yaygın olmayan bazı kavramların açıklanmadan kullanılması da metnin meramını an- 
latması önünde engel teşkil ediyor. Kitabın düşünce açısından içinde olduğu eğilim ise teknolojik determinizm ile açıklanabilir görünüyor. Sinemanın teknolojiye bağımlılığı üzerinden anlaşılmaya çalışılan tarihsel gelişimi sonuçta "hologram sineması" gibi gelecek öngörülerine varıyor. Bu öngörülerin sinemanın kültürel yönünü hafifsediği söylenebilir en azından. Bir diğer sorun da kitabın dijital dönüşümü anlatma vaadine rağmen dijitalleşme sonrası sinemanın anlatıldığı bölümlerin kitabın yarısından azını kapsamış olmasıdır. Kitabın sinema teorisine hasredilmiş bölümleri gereğinden fazla yer kaplıyor.

Sonuç olarak Sinemada Dijital Dönüşüm konuya dair telif bir eser olması ve teorik bir perspektiften eleştirel bir değerlendirme ortaya koyması hasebiyle önemli bir çalışma. Türkiye'de akademik yükselme ve teşvik kriterlerinin kitaptan çok makale yazmayı ödüllendirdiği bir ortamda bir konuyu kitap boyutunda tartışan bütün çalışmalar gibi Sinemada Dijital Dönüşüm entelektüel cömertliğin bir ürünü. Özellikle kendi yorumunu ortaya koyan çalışmaların azlığı kitabı daha da dikkate değer kılıyor. Ayrıca kitap teorik karakteri baskın bir çalışma olarak akademik literatürdeki pratik merkezli çalışmaların oluşturduğu hâkim eğilimden de farklı ve önemli bir yerde duruyor. Teorik çalışmalar arasında ise dayandığı literatürün genişliği, Türkçe düşünmesi ve ele aldığı teorileri belirli bir eleştirel çerçeve içerisinde ifade etmesi gibi özellikleriyle ayrılıyor. Dijitalleşme gibi somut örnekler üzerinden düşünülmeye daha yatkın bir konu için Şentürk'ün felsefi boyut içeren bakış açısının getirdiği görüşler önemli. Sinema ölüyor mu bilinmez ama dönüşen seyir pratiğinin güçlendirdiği "dijital sinema" yeni sorunsalları da beraberinde getiriyor. Sinemada Dijital Dönüşüm de bu sorunsalların tespitine yönelik dikkate değer bir çalışmadır. 


\section{Kaynakça}

Scorsese, M. (2021, Şubat 5). II Maestro: Federico Fellini and the Lost Magic of Cinema. Harper's Magazine. https://harpers.org/archive/2021/03/il-maestro-federico-fellini-martin-scorsese/

Heidegger, M. (2009). Düşünmek Ne Demektir?: 1951/52 Kış Dönemi Ders Notları. Çev. Rıdvan Şentürk. İstanbul: Paradigma.

Şentürk, R. (2011). Postmodern Kaos ve Sinema. İstanbul: Avrupa Yakası.

Şentürk, R. (2013). Eleştirel Teorinin Eleştirisi. İstanbul: Kesit.

Şentürk, R. (2016). Gülme Teorileri. İstanbul: Küre.

Şentürk, R. (2017). İletişim ve Televizyon Teorileri. Küre.

Şentürk, R. (2020). Sinemada Dijital Dönüşüm. İstanbul: Pruva. 
$\underset{\text { pruva }}{\bigcup^{\prime}}$

SINEMADA

DIjIITAL DÖNÜŞÜM

Rıdvan Şentürk

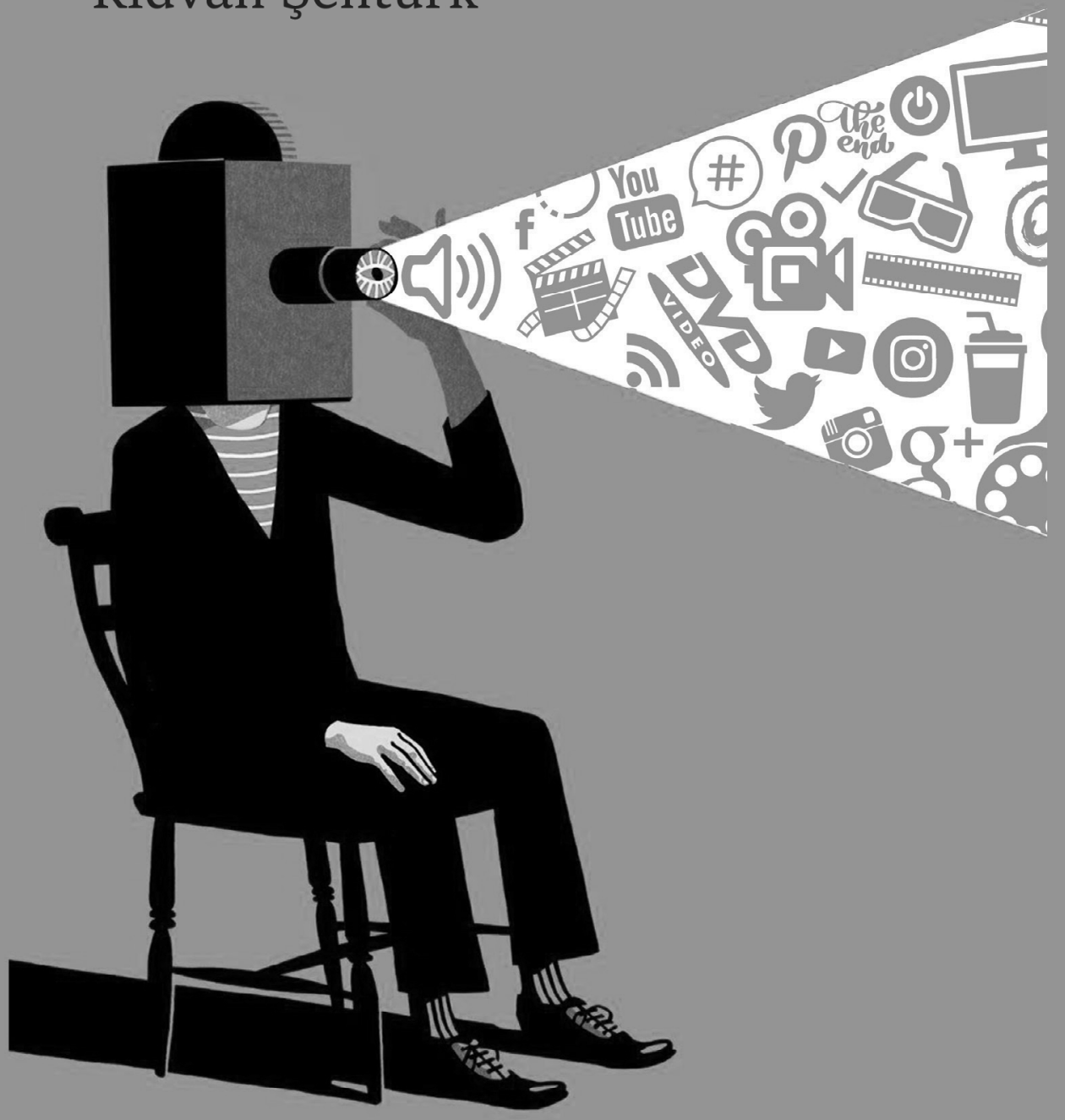

